\title{
RESULTS OF SELECTION OF WINTER DURUM WHEAT IN THE REPUBLIC OF MOLDOVA
}

\author{
Rotary Silvia*, Lyatamborg Svetlana
}

Institute of Genetics, Physiology and Plants Protection, Academy of Sciences of Moldova, Chisinau

\section{РЕЗУЛЬТАТЫ СЕЛЕКЦИИ ОЗИМОЙ ТВЕРДОЙ ПШЕНИЦЫ В РЕСПУБЛИКЕ МОЛДОВА}

\section{Ротарь Сильвия, Лятамборг Светлана}

Received 12.6. 2017

Revised 22.6. 2017

Published 29. 11. 2017

In such a way, using interspecific and intraspecific hybridizations, was created value sources of material for selection of hard winter wheat. By the way of repeated selections, there have been selected from hybrid combinations, highly productive and short - stalk lines which differ between them by high winter hardiness and other value economic and biological characters. All these lines have been studied into various experiences of the selection process (in breeding control and competitive nurseries). The grain yield of the best forms selected from various hybrids have varied from 3.4-4.4 $\mathrm{t} / \mathrm{ha}$ that has been with 0.1-0.9 t/ha more than check variety. Because of work of many years, the plant breeder of our country has created new varieties of this valuable culture that are characterized by good winter hardiness, productivity and the resistance to mealy dew, rust and fusarial diseases. New varieties: Auriu 273, Hordeiforme 333, 335, 340, Auriu 1, 2, 3 are of interest for cultivation in the fields of Republic Moldova and as valuable donors in the process of hybridization and creation of new varieties. On the average, for 4 years the grain yield of these varieties was 3.1-4.9 t/ha. Characteristic of presented varieties was a good winter hardiness, average ripeness, resistance to diseases and to lodging, high technological indexes and others. They have a large grain of amber-yellow color containing a high percent of protein (13-15\%) and gluten (25-30\%). At present 4 (four) sorts (Auriu 273, Hordeiforme 333, 335, 340) are zoned in the Republic of Moldova. Our sorts and forms of hard winter wheat with high productivity have got a big practical value for selection in Moldova. Based on above said, it is possible to draw a conclusion that most of our sorts created by us can be used in crossings as sources and donors of one or a few economic valuable characters and features.

Keywords: winter durum wheat; selection; hybridization; productivity; quality of grain; cultivars

\section{Введение}

Озимая твердая пшеница (Triticum durum Desf.) сравнительно молодая культура, созданная в результате межвидовой и внутривидовой гибридизации. Зерно этой культуры незаменимо в производстве высококачественных макаронных изделий. Используют ее довольно широко в хлебопекарной, крупяной и в кондитерской промышленности. Недостатками форм озимой твердой пшеницы препятствующих получению урожая зерна, равного озимой мягкой 
пшеницы, является слабая их зимостойкость, низкая продуктивная кустистость и сравнительно мелкий колос (Буюкли, 1976; Мудрова, 2014).

Твердая пшеница по своей значимости среди всех видов пшеницы является второй культурой после мягкой и занимает в мире около 18 млн. га или 10 \% от всех посевов пшеницы.

Для озимой твердой пшеницы в Молдове зимостойкость и морозостойкость является одним из важнейших биологических свойств, потому что минимальная температура на глубину залегания узла кущения может снижаться до -15 ... -20 ${ }^{\circ} \mathrm{C}$. В морозные зимы наблюдается гибель растений, что приводит к изреживанию посевов и, как следствие, снижается урожайность зерна. Среди признаков, обеспечивающих адаптивность сортов озимой твердой пшеницы зимостойкость является определяющим, так как в геноме Triticum durum Desf гены зимостойкости изначально отсутствовали (Palade, 2008, 2010; Rotari, Veverita, 2013). Зимостойкость сортов озимой твердой пшеницы детерминируют гены озимой мягкой пшеницы. Продуктивность является главным критерием эффективности селекционной работы любой с/х культуры, в том числе и озимой твердой пшеницы. Выведение нового сорта с максимально возможным уровнем продуктивности является главной задачей современной селекции (Ермакова, 2009; Rotari, 2013).

Основная цель наших исследований - изучить, выделить и создать исходный материал для селекции растений на морозостойкость и продуктивность и в конечном счете вывести сорта озимой твердой пшеницы, сочетающие высокую продуктивность с морозостойкостью и другими хозяйственно-ценными признаками и свойствами.

\section{Матеріали та методи}

Опыты были заложены на полях Института Генетики, Физиологии и Защиты Растений Академии наук, Республика Молдова. Для создания и улучшения новых форм озимой твердой пшеницы использовали межвидовые и внутривидовые скрещивания. В качестве исходного материала были взяты районированные сорта озимой твердой и мягкой пшеницы нашей селекции и самые хорошие сорта из мировой коллекции. В качестве стандарта мы использовали сорт Гордейформе 335. Учетная площадь делянки в селекционном питомнике - 0,6 м², в контрольном питомнике - 5 м $^{2}$ и в конкурсном питомнике - $10 \mathrm{~m}^{2}$. Посев произвели в третьей декаде сентября. Всходы появились через 7 - 8 дней, а кущение - в третьей декаде ноября. В онтогенезе проводились фенологические наблюдения. Были отмечены фазы кущения, выхода в трубку, колошение, цветение, созревание и др. Уборка конкурсного испытания и контрольного питомника выполнялась в один день комбайном «САМПО». Произведен учет продуктивности каждого нового генотипа и сорта.

\section{Результати та їх обговорення}

В целях создания более продуктивных зимостойких и неполегающих форм и сортов озимой твердой пшеницы с длинным многоколосковым колосом и крупным зерном, которые бы по комплексу биологических особенностей и хозяйственных признаков были на уровне лучших сортов озимой мягкой пшеницы, проводили межвидовые и внутривидовые скрещивания. Путем многократных отборов выделены из гибридных комбинаций высокопродуктивные низкостебельные линии, которые отличаются хорошей зимостойкостью, устойчивостью к мучнистой росе, ржавчине и фузариозу.

В последние годы в селекционном питомнике было изучено большое число линий (30 000) из межвидовых и внутривидовых гибридов. В результате всех испытаний мы отобрали 400 низкостебельных линий, которые отличаются хорошей продуктивностью, зимостойкостью и другими ценными хозяйственно-биологическими признаками. Эти формы в последующие годы были изучены в контрольном и конкурсном испытаниях. 
Как видно из данных таблицы, урожай зерна лучших форм, выделенных из различных гибридов, составил 3,4 - 4,4 т/га, что на 0,1 - 0,9 т/га больше стандарта (табл. 1, рис. 1).

Таблица 1 Характеристика линий озимой твердой пшеницы в конкурсном сортоиспытании

Table 1 Characteristics of the lines of winter durum wheat in competitive variety testing

\begin{tabular}{|l|c|c|c|c|c|}
\hline \multirow{2}{*}{ Гибридная комбинация } & \multicolumn{3}{|c|}{ Устойчивость } & \multirow{2}{*}{$\begin{array}{c}\text { Урожайность } \\
\text { т/га }\end{array}$} & $\begin{array}{c}\text { 士 ст. } \\
\text { т/га }\end{array}$ \\
\cline { 2 - 5 } & зимостойкость & $\begin{array}{c}\text { бурая } \\
\text { ржавчина }\end{array}$ & септориоз & & \\
\hline Ауриу 1 & 5 & 1 & 2 & 3,5 & - \\
\hline Ауриу 2 & $5+$ & 0 & 2 & 3,9 & $+0,4$ \\
\hline Ауриу 3 & $5+$ & 1 & 1 & 3,9 & $+0,4$ \\
\hline Горд. 333/Горд. 335 & 5 & 2 & 2 & 3,4 & $-0,1$ \\
\hline Омраби/Днепрянка & 5 & 2 & 1 & 3,9 & 0,4 \\
\hline ио Кристалл 2 & $5+$ & 0 & 2 & 4,4 & 0,9 \\
\hline Горд. 335/1162 (Болгария) & 5 & 1 & 2 & 3,8 & $+0,3$ \\
\hline Горд. 335/(1162/Ауриу 273) & 5 & 2 & 2 & 3,8 & $+0,3$ \\
\hline Горд. 335, стандарт & 4 & 2 & 2 & 3,5 & - \\
\hline
\end{tabular}

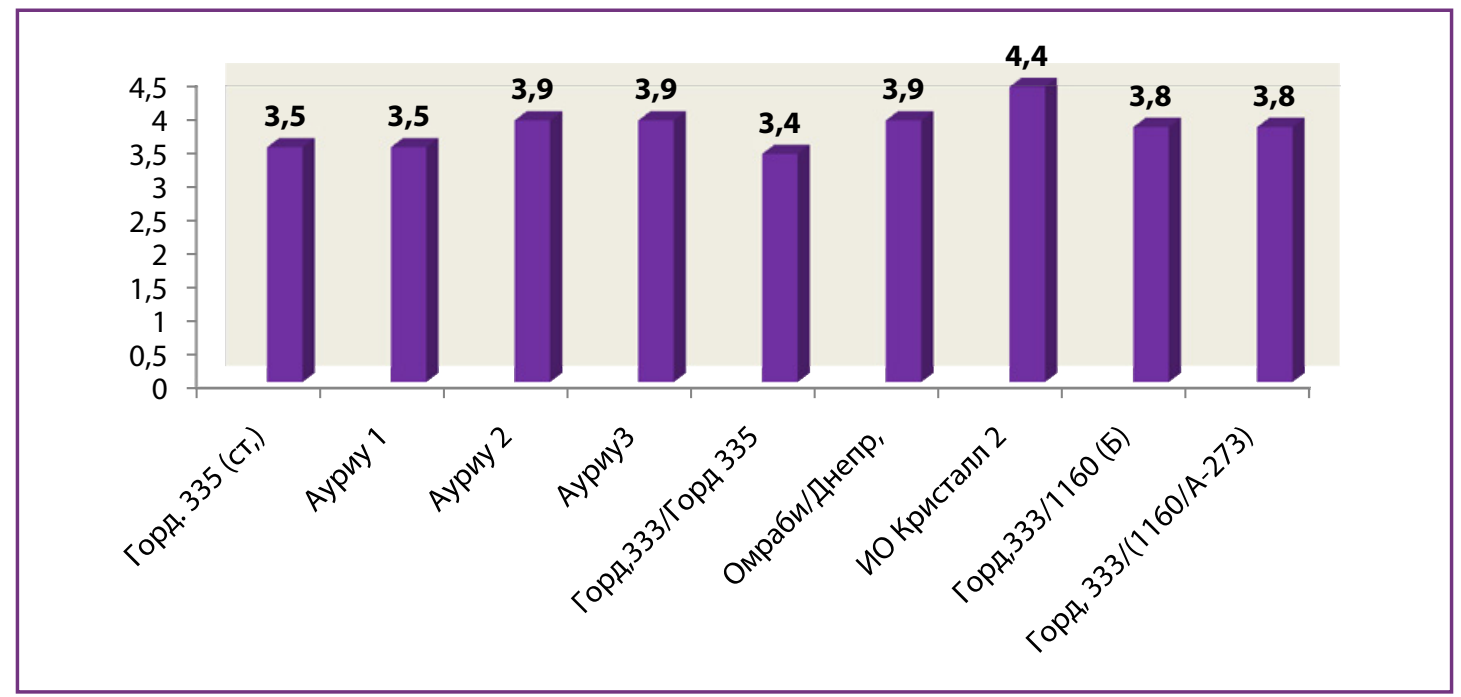

Рисунок 1 Урожай зерна лучших линий конкурсного сортоиспытания, т/га

Figure 1 Grain harvest of the best lines of competitive variety testing, t/ha

Изучение новых линий в контрольном и конкурсном питомниках позволило нам выбрать некоторые из них, которые превосходят самые лучшие сорта по продуктивности и устойчивости к абиотическим и биотическим факторам среды. В результате всей этой работы в последние годы были созданы сорта озимой твердой пшеницы: Ауриу 1, 2, 3. Характерной особенностью приведенных сортов является хорошая зимостойкость, среднеспелость, устойчивость к болезням и полеганию, высокие технологические показатели и другие. Они 
имеют крупное зерно янтарно-желтого цвета, содержащее высокий процент белка (13 - 15 \%) и клейковины (25 - $30 \%)$.

В результате многолетней работы селекционеров нашей страны за последнее время были созданы много сортов этой ценной зерновой культуры с хорошей зимостойкостью, продуктивностью и другими хозяйственно-ценными признаками. В настоящее время 4 сорта районированы в Республике Молдова (Гордейформе 333, 335, 340 и Ауриу 273). У этих сортов озимой твердой пшеницы в последние 4 года урожай составил $3.1-4.9$ т/га (рис. 2). Новые сорта: Ауриу 273, Гордейформе 333, 335, 340, Ауриу 1, 2, 3 представляют интерес для возделывания в сельском хозяйстве, как ценные доноры в гибридизации и селекции пшеницы для создания новых сортов.

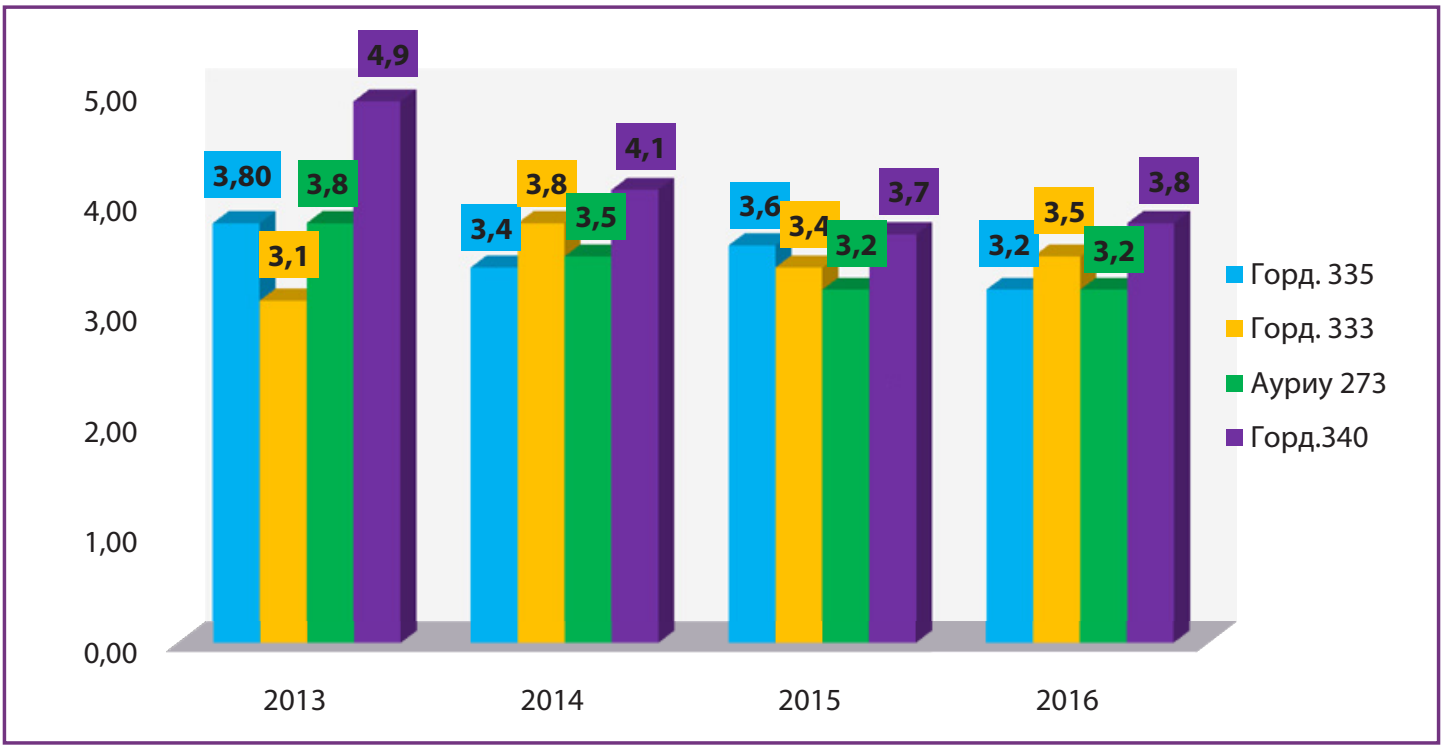

Рисунок 2 Продуктивность наших районированных сортов в последние 4 года (2013 - 2016), т/га Figure 2 Productivity of our regionalized varieties in the last 4 years (2013-2016), t/ha

Выделившиеся по высокой продуктивности сорта озимой твердой пшеницы представляют большую практическую ценность для селекции в Молдове. Исходя из выше сказанного, можно сделать вывод о том, что большинство созданных нами сортов могут быть использованы в скрещиваниях как источники и доноры одного или нескольких хозяйственно-ценных признаков.

\section{Висновки}

Методами межвидовой и внутривидовой гибридизаций создан ценный исходный материал для селекции озимой твердой пшеницы. Путем многократных отборов выделены из гибридных популяций высокопродуктивные низкостебельные линии, которые отличаются хорошей зимостойкостью и другими ценными хозяйственными и биологическими признаками. В результате многолетней работы селекционеров нашей страны за последнее время выведен ряд новых сортов этой ценной культуры, которые отличаются высокой зимостойкостью, продуктивностью и другими ценными биолого-хозяйственными признаками. В настоящее время 4 сорта (Ауриу 273, Гордейформе 333, 335, 340) районированы в Республике Молдова. Новые сорта: Ауриу 273, Гордейформе 333, 335, 340, Ауриу 1, 2, 3 представляют интерес 
для возделывания в сельском хозяйстве и как ценные доноры в гибридизации и селекции пшеницы с целью создания новых сортов.

\section{Література}

Palade, N. 2008. Grâul durum de toamnă în condiţiile climaterice extremale ale anilor 2006-2007. Lucrări ştiinţifice UASM, vol. 20, p. 72. CZU 016: 378.663.

Palade, N. 2010. Grâul durum de toamnă în condiţiile climatice contraste ale anilor 2007-2008. Ştiinţa agricolă. UASM, no. 1, p. 122. ISSN 1857-0003.

Rotari, S. 2013. Productivitatea şi calitatea boabelor de grâu durum de toamnă. Mat. Conf. Inter. Impactul realizărilor ştiinţifice asupra producţiei şi calităţii cerealelor spicoase, Republica Moldova, Bălţi, p. 56-62. ISBN 978-9975-53-224-2.

Rotari, S., Veverita, E. 2013. Rezistenţa grăului durum de toamnă la iernare, secetă, cădere şi boli. Materialele Simpozionului Științific Internațional "Agricultura Modernă - Realizări și Perspective" consacrat aniversării de 80 de ani de la Înfiinţarea Universităţii Agrare de Stat din Moldova, Agronomie şi Ecologie, vol. 39, p. 290-93. ISBN 978-9975-64-250-7.

Буюкли, П. 1976. Селекция озимой твердой пшеницы в Молдавии. Кишинев: Штиинца, 162 с. ISBN 9975-64-033-8.

Ермакова, Н. 2009. Особенности развития формирования урожая и качества зерна озимой твердой и тургидной пшеницы в Лесостепи ЦРС: афтореф. дисс. кандидата с.-х. Наук. Воронеж. 23 с.

Мудрова, А. 2014. Селекция озимой твердой пшеницы на Кубани. Краснодар: КНИИСХ, 190 с. 